\title{
It is possible to maintain productivity and quality standards in carnation with less nitrogen in the fertigation formula
}

\section{Es posible mantener estándares de productividad y calidad en clavel con menos nitrógeno en la fórmula de fertirriego}
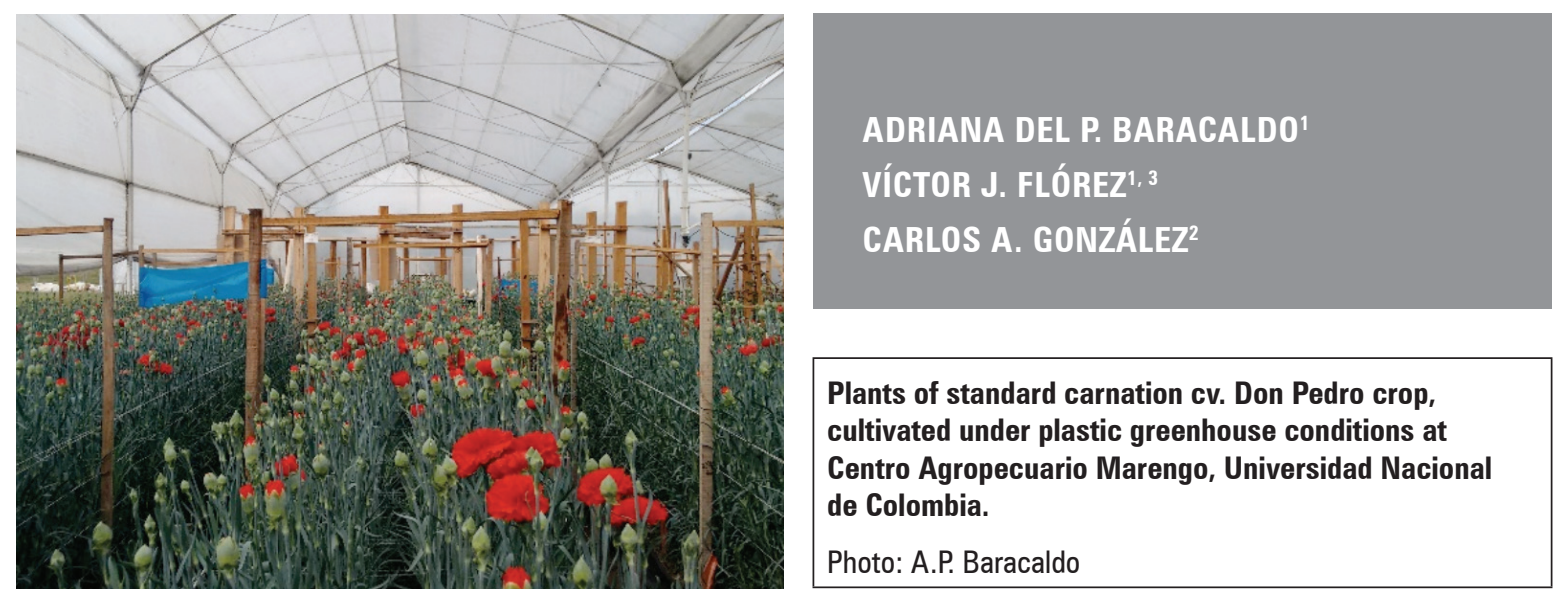

Plants of standard carnation cv. Don Pedro crop, cultivated under plastic greenhouse conditions at Centro Agropecuario Marengo, Universidad Nacional de Colombia.

Photo: A.P. Baracaldo

\section{ABSTRACT}

Although nitrogen is the most widely used fertilizer in agriculture, it contaminates the surface and groundwater through leaching. A decrease in the concentration of total nitrogen and changes in the ammonium:nitrate ratio can provide information for a better use of this nutrient. The objective of this study was to

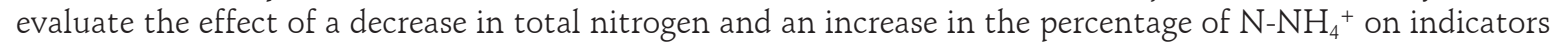
of growth, productivity, quality and nitrogen use efficiency (NUE) in carnation cultivation. In the Centro Agropecuario Marengo at the Universidad Nacional de Colombia, two concentrations of total nitrogen were evaluated (200-140 $\mathrm{mg} \mathrm{L}^{-1}$ in the vegetative phase and 160-112 $\mathrm{mg} \mathrm{L}^{-1}$ in the productive phase) with three ra-

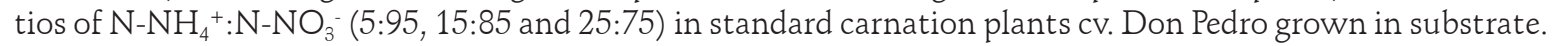
In both fertigation formulas, similar productivity and qualities were obtained, and the formula with less total $\mathrm{N}$ provided better NUE, mitigating the negative impact of this nutrient on the environment. Likewise, the ammoniacal component played a preponderant role: the number of flowering stems per plant decreased as the ammoniacal component increased, similar to that observed with the percentage of flowering stems in the 'Select' quality grade.

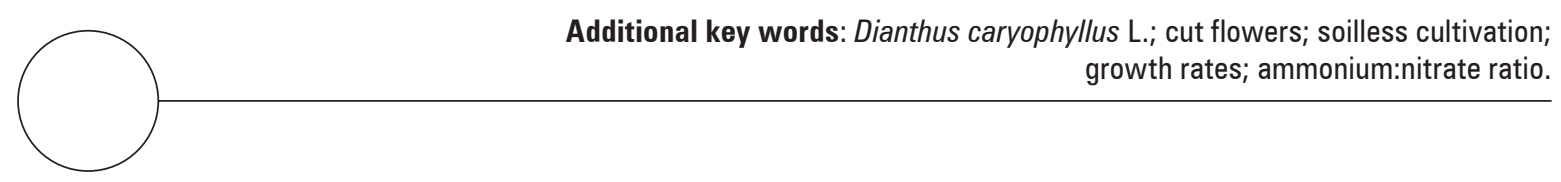

\footnotetext{
1 Universidad Nacional de Colombia, Facultad de Ciencias Agrarias, Departamento de Agronomía, Bogota (Colombia). ORCID Baracaldo, A.P.: 0000-0001-7947-3510; ORCID Flórez, V.J.: 0000-0002-3081-2400

2 Universidad Nacional de Colombia, Facultad de Ingeniería, Departamento de Ingeniería Civil y Agrícola, Bogota (Colombia). ORCID González, C.A.: 0000-0002-2920-8425

3 Corresponding author.vjflorezr@unal.edu.co
} 


\section{RESUMEN}

Aunque el nitrógeno es el fertilizante más usado en la agricultura contribuye a contaminar aguas superficiales y subterráneas a través de su lixiviación. Una disminución en la concentración del nitrógeno total y cambios en la relación amonio:nitrato pueden proveer información acerca de una mejor utilización de este nutriente. El objetivo de este estudio fue evaluar el efecto de la disminución del nitrógeno total y el aumento del porcentaje de $\mathrm{N}_{-} \mathrm{NH}_{4}{ }^{+}$ sobre indicadores del crecimiento, la productividad, la calidad y la eficiencia del uso del nitrógeno (EUN) en el cultivo de clavel. Para lo cual, en el Centro Agropecuario Marengo de la Universidad Nacional de Colombia se evaluaron dos concentraciones de nitrógeno total (200-140 $\mathrm{mg} \mathrm{L}^{-1}$ en fase vegetativa y $160-112 \mathrm{mg} \mathrm{L}^{-1}$ en fase productiva) con

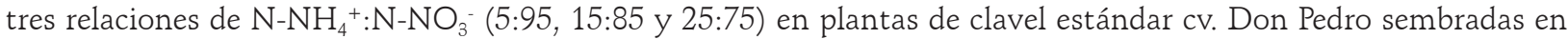
sustrato. En ambas fórmulas de fertirriego se obtuvieron productividades y calidades similares y en aquella fórmula con menos $\mathrm{N}$ total mejor EUN, mitigando el impacto negativo de este nutriente en el medio ambiente. Así mismo, el componente amoniacal juega un papel preponderante: el número de tallos florales por planta disminuiría en la medida que se aumenta el componente amoniacal, de manera similar a lo observado con el porcentaje de tallos florales en grado de calidad Select.

Palabras clave adicionales: Dianthus caryophyllus L.; flores de corte; cultivo sin suelo; índices de crecimiento; relación amonio:nitrato.

Received for publication: 06-06-2018 Accepted for publication: 31-07-2019

INTRODUCTION

The use of nitrogen fertilizers is excessive worldwide, causing pollution problems (Cameron et al., 2013; Schipper et al., 2010; Zhang et al., 2011; Daza et al., 2015). It is estimated that, in 2020, approximately 201.7 million tons of NPK-based fertilizers will be used, of which $58.9 \%$ will correspond to nitrogen (FAO, 2017). The application of $\mathrm{N}$ worldwide has increased more than eight-fold since 1961 (Kant, 2018). In Colombia, the consumption of these agricultural inputs has increased significantly since 2000 despite the fact that no significant increase was observed in the agricultural use area (ICA and MADR, 2015). Locally, fertilization in soilless cultivation systems is based on empirical practices, which generally leads to producers overestimating the needs of plants and applying excessive amounts, with a consequent waste of nutrients and money and risk of contamination for water courses and groundwater. One of the most important objectives for the development of sustainable agriculture is increasing crop yield and quality while using less nitrogen fertilizers and, thereby, improving Nitrogen Use Efficiency (NUE) (Good et al., 2004; Lupini et al., 2017).

The importance of nitrogen for plant development, its essentiality, the compounds it is a part of (Kiba et al., 2011), its influence on metabolic processes (Jin et al., 2015), its role in water use efficiency (Ucar et al., 2017), and the symptoms of its deficiency and toxicity (Gárate and Bonilla, 2013) are widely described in the literature as are the metabolic processes of nitrogen assimilation (Maldonado et al., 2013), the influence of environmental factors and species (Cabrera, 2006), and its mobility, storage, enzyme complexes, organelles and energy sources involved in reduction to ammonium (Barker and Bryson, 2007; Kant, 2018).

Plants have developed mechanisms to modulate efficiency of $\mathrm{N}$ uptake in response to factors, such as the availability and form of $\mathrm{N}$ present in the soil solution as well as to the $\mathrm{N}$ requirement of the plants during the life cycle (Hawkesford et al., 2012).

Strategies for mitigating the impact of nitrogen as a contaminant include lowering the total nitrogen input and increasing the percentage of ammonium. For the efficient use of this nutrient, Kumar et al. (2016) showed that, with $0,50,100,150$ and $200 \mathrm{mg} \mathrm{L}^{-1}$ of $\mathrm{N}$ in carnation plants cv. Red Corso, the values of the evaluated variables (number of flower buds per plant, number of flowers per plant, flower size, flower weight, stem length and flower duration) increased significantly up to $150 \mathrm{mg} \mathrm{L}^{-1}$. In several crops, combinations of both forms $\left(\mathrm{N}-\mathrm{NH}_{4}{ }^{+}\right.$and $\left.\mathrm{N}-\mathrm{NO}_{3}{ }^{-}\right)$usually 
result in higher growth than when only one of the forms is used (Vojtíšková et al., 2004; Li et al., 2007). In anthurium, Dufour and Guerin (2005), when using $\mathrm{NH}_{4}{ }^{+}: \mathrm{NO}_{3}{ }^{-}$ratios of $0.25,0.37$ and 0.51 in the nutrient solution, found that increasing the ratio to 0.37 of the total $\mathrm{N}$ improved the growth, development and plant yield. Khalaj et al. (2017) evaluated the effect of $\mathrm{NO}_{3}^{-}: \mathrm{NH}_{4}^{+}(100: 0,80: 20,60: 40,40: 60)$ ratios in the fertigation solution on gerbera cvs. Stanza and Double Dutch. The 80:20 ratio presented higher values in the evaluated variables (number of leaves per plant, number of flowers, diameter of the stem and flower, fresh and dry mass of roots and shoots and vase life), and, with the 40:60 ratio, the plant growth and biomass were significantly reduced. With the increase in the concentration of ammonium, the carotenoid and chlorophyll contents increased as well as the catalase and peroxidase activity in cells. For a given dose of $\mathrm{N}$ and irrigation regime, according to Bar-Yosef (2008), the aforementioned ratios affect several factors in the soil solution and crop: i) nitrogen uptake efficiency; ii) decreased uptake rates for $\mathrm{Ca}^{+2}, \mathrm{Mg}^{+2}$ and $\mathrm{K}^{+}$as the result of competition with $\mathrm{NH}_{4}{ }^{+}$uptake; iii) $\mathrm{NH}_{4}{ }^{+}$ decreases the $\mathrm{pH}$ of the solution while $\mathrm{NO}_{3}{ }^{-}$increases it; and iv) excessive uptake of $\mathrm{NH}_{4}^{+}$, particularly at temperatures higher than $28^{\circ} \mathrm{C}$ in the root zone, is detrimental to the development of roots.

Tabatabaei et al. (2006) found in a hydroponic strawberry crop that high $\mathrm{NH}_{4}{ }^{+}$and $\mathrm{NO}_{3}{ }^{-}$ratios in the fertigation solution always reduced the yield and that the $25 \mathrm{NH}_{4}{ }^{+}: 75 \mathrm{NO}_{3}{ }^{-}$ratio increased the yield by $38 \%$ and $84 \%$ in cvs. Camarosa and Jungle, respectively. The higher yield with this ratio resulted from increases in the size, length and fresh mass of the fruits; however, the 0 to $75 \%$ increase in the $\mathrm{NH}_{4}^{+}$ ratio significantly reduced the concentration of fruit $\mathrm{Ca}$ and postharvest life of both cultivars. Apparently, a greater foliar area and photosynthesis rate with the 25:75 $\mathrm{N}$ ratio were the reasons for the increases in productivity and plant growth. For Roosta (2014), the adverse effects of alkalinity on SPAD values and the maximum quantum yield of PSII (Fv/Fm) were alleviated with increases in the proportion of $\mathrm{NH}_{4}{ }^{+}$ in the nutrient solution, increasing the number of fruits and yield in strawberry cv. Camorosa. Among the treatments studied by Abasi et al. (2016) in a hydroponic cultivation of tulip cvs. Apricot Parrot and Daytona with a $\mathrm{NH}_{4}{ }^{+} / \mathrm{NH}_{4}{ }^{+}+\mathrm{NO}_{3}{ }^{-}$ratio of 0.38 in the nutritive solution, they found the maximum concentrations of $\mathrm{Ca}$ and $\mathrm{Mg}$, floral longevity, dry mass and optimal N, P, K. For these reasons, specific studies are required for each species in order to find the best $\mathrm{NH}_{4}{ }^{+}: \mathrm{NO}_{3}^{-}$ratio.

The objective of this study was to evaluate the effect of the lesser rate of total nitrogen and an increase in the percentage of $\mathrm{N}_{-} \mathrm{NH}_{4}{ }^{+}$on indicators of growth, productivity, quality and nitrogen use efficiency in standard carnation crop cv. Don Pedro.

\section{MATERIALS AND METHODS}

This research was carried out at the Centro Agropecuario Marengo (CAM) at the Universidad Nacional de Colombia, Bogota campus, located in the municipality of Mosquera (Cundinamarca) at $4^{\circ} 42^{\prime} \mathrm{N}$ and $74^{\circ} 12^{\prime}$ $\mathrm{W}$, at $2540 \mathrm{~m}$ a.s.l., with an average temperature of $12.4^{\circ} \mathrm{C}$, relative humidity between 76 and $89 \%$ and annual average rainfall of $1,124 \mathrm{~mm}$ (Ordoñez and Bolivar, 2014). During the study, the average temperature and relative humidity inside the greenhouse were $17.5^{\circ} \mathrm{C}$ and $76 \%$, respectively.

For the test, a traditional greenhouse with a flexontype metal structure (Acuña and Ortiz, 2004) was used, with passive lateral and zenithal ventilation, in which two warehouses, $9 \times 70 \mathrm{~m}\left(630 \mathrm{~m}^{2}\right)$, were fitted. Six wooden beds $(7.0 \times 0.7 \mathrm{~m})$ were built, raised $0.4 \mathrm{~m}$ from the ground, with a double container, each measuring $0.25 \mathrm{~m}$ wide and $0.2 \mathrm{~m}$ deep, and a leachate collection tank at the end of each bed. Standard carnation (Dianthus caryophyllus L.) cv. Don Pedro cuttings were used at a density of 15.5 plants per $\mathrm{m}^{2}$ in an open substrate cultivation system. The substrate consisted of a mixture of $50 \%$ raw rice husk $+15 \%$ burnt rice husk $+25 \%$ reused burnt rice husk $+10 \%$ compost, obtained from rose and carnation crop residues (v/v/v/v). The initial EC and $\mathrm{pH}$ of this mixture were $0.5-1.0 \mathrm{dS} \mathrm{m}^{-1}$ and $6.8-7.0$, respectively. The agronomic crop management described in Flórez et al. (2006a) was used.

Six treatments were established, corresponding to modifications in the $\mathrm{N}$ content of the conventional formula, commercially applied in the carnation crop (200-160 $\mathrm{mg} \mathrm{L}^{-1}$ of total $\mathrm{N}$ for the vegetative and productive phases of the crop, respectively, maintaining a $\mathrm{NH}_{4}{ }^{+}: \mathrm{NO}_{3}{ }^{-}$ratio equal to15:85). In this formula, the total $\mathrm{N}$ was reduced by $30 \%$, and the $\mathrm{NH}_{4}{ }^{+}: \mathrm{NO}_{3}{ }^{-}$ratio was decreased or increased by $10 \%$ (Tab. 1). In the fertigation solutions, the EC remained between 1.5 and 2.5, and the $\mathrm{pH}$ was between 5.5 and 6.0. The concentrations of the elements $\left(\mathrm{mg} \mathrm{L}^{-1}\right)$ in the vegetative 
and reproductive phases were: $\mathrm{P}, 30 ; \mathrm{K}, 150 ; \mathrm{Ca}, 120$; $\mathrm{Mg}, 40 ; \mathrm{Fe}, 3$; Cu, 1; Zn, 0.5; B, 1; Mo, 0.1; and $\mathrm{S}$, between 2 and $116 \mathrm{mg} \mathrm{L}^{-1}$ because it was used for the stoichiometric balance of the $\mathrm{NH}_{4}{ }^{+}$in the formula. In order to calculate the nutritional solutions, the contribution of water $(\mathrm{EC}=0.6$ and $\mathrm{pH}=7.0)$ and $\mathrm{Mn}$ in the burnt rice husk substrate (Florian-Martínez and Roca, 2011) were taken into account.

For the analysis of growth at 16, 21 and 26 weeks after sowing (WAS) in the production cycle, three destructive samples were carried out in order to measure the variables leaf area and dry mass of root and shoot, separated into dry mass of stems, leaves and flower buds. The leaf area $\left(\mathrm{cm}^{2}\right)$ was determined with LI-COR model LI-3100. Based on these data and in accordance with Flórez et al. (2006b), the Relative Growth Rate (RGR), the Leaf Area Index (LAI), the Specific Leaf Area (SLA), the Leaf Mass Ratio (LMR) and the Net Assimilation Rate (NAR) were calculated. From 10 WAS, six plants were randomly selected biweekly per treatment for continuous growth measurements. The number of stems per plant was counted, and the length and diameter of the stem, the number of leaves, and the length and diameter of the flower bud were measured on the middle stem of each plant.

The productivity and quality of the carnation flower stalks were recorded for each of the treatments. Productivity was expressed as the number of flowering stems produced per $\mathrm{m}^{2}$ of greenhouse area, and quality was the percentages of stems according to the parameters of the select, fancy, standard and national grades. This classification was determined, among other characteristics, with the length and strength of the stems, the size and opening point of the flowers, defects in quality attributes or parameters and the presence of pests or diseases, as described by Reid and Hunter (2000) and Escandón (2009).

To determine the Nitrogen Use Efficiency (NUE) in the samples of complete plants by treatment at 16, 21 and 26 WAS, the content of $\mathrm{N}$ in the vegetal tissue was determined. The analyses were performed in the Laboratorio de Aguas y Suelos de la Facultad de Ciencias Agrarias at the Universidad Nacional de Colombia, according to the procedures described by Carrillo et al. (1994): N (total nitrogen) micro-Kjeldahl methodology. The NUE was calculated taking into account the dry mass accumulation and nitrogen uptake, agreeing to Good et al. (2004); according to the following formula: NUE = dry mass of complete plant (g)/nitrogen content in complete plant (g).

\section{Statistical analysis}

A completely randomized experimental design was used, with a factorial arrangement of two levels of total nitrogen and three $\mathrm{NH}_{4}{ }^{+}: \mathrm{NO}_{3}{ }^{-}$ratios (Tab. 1). The six treatments had three replicates, and the experiment unit consisted of $2 \mathrm{~m}$ of bed with 46 plants. The inferential analysis was carried out with analysis of variance (Anova) and multiple comparison Tukey test, with a level of significance $P \leq 0.05$. Normality and homogeneity of variance in the residuals were verified by means of the Shapiro-Wilk and Levene tests, respectively, to validate the adjusted model. All analyses were performed with the statistical software SAS v. 9.1.

Table 1. Nitrogen concentrations and ratios evaluated in the fertigation formula used in the cultivation of carnation cv. Don Pedro grown in substrate.

\begin{tabular}{|c|c|c|c|c|c|c|c|c|}
\hline \multirow{3}{*}{\multicolumn{2}{|c|}{ Treatments }} & \multirow{3}{*}{$\frac{\mathrm{NH}_{4}{ }^{+}: \mathrm{NO}_{3}{ }^{-}}{(\%)}$} & \multicolumn{3}{|c|}{ Vegetative phase } & \multicolumn{3}{|c|}{ Productive phase } \\
\hline & & & $\mathrm{NH}_{4}^{+}$ & $\mathrm{NO}_{3}^{-}$ & Total N & $\mathrm{NH}_{4}^{+}$ & $\mathrm{NO}_{3}^{-}$ & Total N \\
\hline & & & \multicolumn{6}{|c|}{$\left(\mathrm{mg} \mathrm{L}^{-1}\right)$} \\
\hline \multicolumn{2}{|l|}{$5 \% \mathrm{~N}^{-\mathrm{NH}_{4}}{ }^{+}$} & $5: 95$ & 10 & 190 & \multirow{3}{*}{200} & 8 & 152 & \multirow{3}{*}{160} \\
\hline \multicolumn{2}{|l|}{$15 \% \mathrm{~N}^{-\mathrm{NH}_{4}}{ }^{+}$} & $15: 85$ & 30 & 170 & & 24 & 136 & \\
\hline \multicolumn{2}{|l|}{$25 \% \mathrm{~N}^{-\mathrm{NH}_{4}+}$} & $25: 75$ & 50 & 150 & & 40 & 120 & \\
\hline \multirow{3}{*}{$30 \%$ less $N$} & $5 \% \mathrm{~N}^{-\mathrm{NH}_{4}}{ }^{+}$ & $5: 95$ & 7 & 133 & \multirow{3}{*}{140} & 5.6 & 106.4 & \multirow{3}{*}{112} \\
\hline & $15 \% \mathrm{~N}^{-\mathrm{NH}_{4}}{ }^{+}$ & $15: 85$ & 21 & 119 & & 16.8 & 95.2 & \\
\hline & $25 \% \mathrm{~N}^{-\mathrm{NH}_{4}}{ }^{+}$ & $25: 75$ & 35 & 105 & & 28 & 84 & \\
\hline
\end{tabular}




\section{RESULTS AND DISCUSSION}

\section{Continuous growth analysis}

Among the treatments evaluated, the formula with less total $\mathrm{N}$ and a lower percentage of $\mathrm{NH}_{4}{ }^{+}$(140$112 \mathrm{~N}-5 \% \mathrm{~N}^{-\mathrm{NH}_{4}}{ }^{+}$) presented a number of stems per plant significantly higher than the formula with more total $\mathrm{N}$, with the highest percentages of ammoniacal component; meanwhile, no significant differences were found for the variables length and diameter of the flowering stem (Tab. 2). There were no significant statistical differences in the variables number of leaves (average of 29.1 leaves per stem), length (between 42 and $53 \mathrm{~mm}$ ) and diameter (average of 22 $\mathrm{mm}$ ) of the floral bud (data not shown). It was evident that it is feasible to maintain quality attributes and even improve productivity with a more conservative fertigation formula for the nitrogen component.

This finding is consistent with the significant increases in productivity and quality variables reported by Kumar et al. (2016) with up to $150 \mathrm{mg} \mathrm{L}^{-1}$ of $\mathrm{N}$ in carnation plants cv. Red Corso. For $\mathrm{NO}_{3}{ }^{-}: \mathrm{NH}_{4}{ }^{+}$ratios, similar to that reported here, Khalaj et al. (2017) obtained the highest values for variables evaluated in Gerbera cvs. Stanza and Double Dutch with the lowest percentage of ammonium, i.e. the 80:20 ratio. On the other hand, Dufour and Guerin (2005) found improvements in development and yield in anthurium with increases in the $\mathrm{NH}_{4}{ }^{+}: \mathrm{NO}_{3}{ }^{-}$ratio, up to 0.37 of the total $\mathrm{N}$.

This study confirmed that concentrations of 140 $112 \mathrm{mg} \mathrm{L}^{-1}$ of $\mathrm{N}$ in the vegetative and reproductive

Table 2. Length, diameter and number of the flowering stems per plant of standard carnation cv. Don Pedro planted in substrate and subjected to a decrease in total $\mathbf{N}$ and increases in the ammoniacal component in the fertigation formula.

\begin{tabular}{|c|c|c|c|c|c|c|c|c|c|c|}
\hline \multirow{2}{*}{\multicolumn{2}{|c|}{ Treatments }} & \multicolumn{9}{|c|}{ Week after sowing } \\
\hline & & 10 & 12 & 14 & 16 & 18 & 20 & 22 & 24 & 26 \\
\hline Total N (mg L-1) & $\mathrm{N}-\mathrm{NH}_{4}{ }^{+}(\%)$ & \multicolumn{9}{|c|}{ Stem length $(\mathrm{cm})$} \\
\hline \multirow{3}{*}{$200-160 *$} & 5 & $12.5 \mathrm{a}$ & $16.9 a b$ & 26.6 a & $37.5 \mathrm{a}$ & $56.8 \mathrm{a}$ & $76.5 \mathrm{a}$ & $82.6 \mathrm{a}$ & $88.3 \mathrm{a}$ & $92.8 \mathrm{a}$ \\
\hline & 15 & $14.1 \mathrm{a}$ & $17.0 \mathrm{ab}$ & $28.0 \mathrm{a}$ & $42.7 \mathrm{a}$ & $66.0 \mathrm{a}$ & $81.3 \mathrm{a}$ & $86.6 \mathrm{a}$ & $86.6 \mathrm{a}$ & $87.5 \mathrm{a}$ \\
\hline & 25 & $14.3 \mathrm{a}$ & $18.3 a b$ & $27.8 \mathrm{a}$ & $42.8 \mathrm{a}$ & $63.5 \mathrm{a}$ & $78.8 \mathrm{a}$ & $85.7 \mathrm{a}$ & $87.2 \mathrm{a}$ & $88.0 \mathrm{a}$ \\
\hline \multirow{3}{*}{$140-112^{*}$} & 5 & $13.9 \mathrm{a}$ & $18.7 a b$ & $28.3 \mathrm{a}$ & $42.2 \mathrm{a}$ & $62.0 \mathrm{a}$ & $79.5 \mathrm{a}$ & $87.5 \mathrm{a}$ & 88.6 a & $88.6 \mathrm{a}$ \\
\hline & 15 & $14.0 \mathrm{a}$ & $20.5 \mathrm{a}$ & $30.1 \mathrm{a}$ & $45.4 \mathrm{a}$ & $62.8 \mathrm{a}$ & $79.4 \mathrm{a}$ & $84.7 \mathrm{a}$ & $90.4 \mathrm{a}$ & $91.8 \mathrm{a}$ \\
\hline & 25 & $13.4 \mathrm{a}$ & $15.7 \mathrm{~b}$ & $23.2 \mathrm{a}$ & $39.5 \mathrm{a}$ & $60.9 \mathrm{a}$ & $77.8 \mathrm{a}$ & $85.3 \mathrm{a}$ & $87.8 \mathrm{a}$ & $89.0 \mathrm{a}$ \\
\hline \multicolumn{2}{|l|}{ Standard error } & 0.36 & 0.41 & 0.77 & 1.37 & 1.98 & 1.17 & 1.16 & 1.08 & 1.25 \\
\hline Total $\mathrm{N}\left(\mathrm{mg} \mathrm{L}^{-1}\right)$ & $\mathrm{N}-\mathrm{NH}_{4}{ }^{+}(\%)$ & \multicolumn{9}{|c|}{ Stem diameter $(\mathrm{mm})$} \\
\hline \multirow{3}{*}{$200-160 *$} & 5 & $5.1 \mathrm{a}$ & $5.6 \mathrm{a}$ & $6.3 \mathrm{a}$ & $6.4 \mathrm{a}$ & $6.4 \mathrm{a}$ & $6.2 \mathrm{a}$ & $6.4 \mathrm{a}$ & $6.5 \mathrm{a}$ & $6.2 \mathrm{a}$ \\
\hline & 15 & $5.8 \mathrm{a}$ & $6.5 \mathrm{a}$ & $7.1 \mathrm{a}$ & $7.4 \mathrm{a}$ & $7.3 \mathrm{a}$ & $7.0 \mathrm{a}$ & $6.8 \mathrm{a}$ & $6.9 \mathrm{a}$ & $6.9 \mathrm{a}$ \\
\hline & 25 & $5.2 \mathrm{a}$ & $5.9 \mathrm{a}$ & $6.8 \mathrm{a}$ & $7.1 \mathrm{a}$ & $7.1 \mathrm{a}$ & $7.0 \mathrm{a}$ & $6.8 \mathrm{a}$ & $6.8 \mathrm{a}$ & $6.8 \mathrm{a}$ \\
\hline \multirow{3}{*}{$140-112^{*}$} & 5 & $4.3 \mathrm{a}$ & $5.5 \mathrm{a}$ & $6.8 \mathrm{a}$ & $7.3 \mathrm{a}$ & $7.2 \mathrm{a}$ & $6.9 \mathrm{a}$ & $6.4 \mathrm{a}$ & $6.4 \mathrm{a}$ & $6.4 \mathrm{a}$ \\
\hline & 15 & $5.6 \mathrm{a}$ & $6.1 \mathrm{a}$ & $6.6 \mathrm{a}$ & $7.0 \mathrm{a}$ & $6.8 \mathrm{a}$ & $6.7 \mathrm{a}$ & $6.7 \mathrm{a}$ & $6.8 \mathrm{a}$ & $6.6 \mathrm{a}$ \\
\hline & 25 & $5.3 \mathrm{a}$ & $6.2 \mathrm{a}$ & $6.8 \mathrm{a}$ & $7.3 \mathrm{a}$ & $7.1 \mathrm{a}$ & $6.9 \mathrm{a}$ & $6.6 \mathrm{a}$ & $6.6 \mathrm{a}$ & $6.5 \mathrm{a}$ \\
\hline \multicolumn{2}{|l|}{ Standard error } & 0.15 & 0.10 & 0.09 & 0.10 & 0.10 & 0.12 & 0.09 & 0.09 & 0.11 \\
\hline Total N $\left(\mathrm{mg} \mathrm{L}^{-1}\right)$ & $\mathrm{N}-\mathrm{NH}_{4}{ }^{+}(\%)$ & \multicolumn{9}{|c|}{ Number of stems per plant } \\
\hline \multirow{3}{*}{$200-160^{*}$} & 5 & $8.3 \mathrm{a}$ & $8.5 a b$ & $8.8 a b$ & $9.2 a b$ & $9.2 \mathrm{ab}$ & $8.8 \mathrm{ab}$ & $8.8 \mathrm{ab}$ & $8.8 \mathrm{ab}$ & $8.8 \mathrm{ab}$ \\
\hline & 15 & $7.7 \mathrm{a}$ & $7.8 \mathrm{~b}$ & $7.8 \mathrm{~b}$ & $7.8 \mathrm{~b}$ & $7.8 \mathrm{~b}$ & $7.8 \mathrm{~b}$ & $7.8 \mathrm{~b}$ & $7.8 \mathrm{~b}$ & $7.8 \mathrm{~b}$ \\
\hline & 25 & $7.8 \mathrm{a}$ & $8.2 a b$ & $8.2 a b$ & $8.2 \mathrm{~b}$ & $8.2 \mathrm{~b}$ & $8.2 \mathrm{~b}$ & $8.2 \mathrm{~b}$ & $8.2 \mathrm{~b}$ & $8.1 \mathrm{~b}$ \\
\hline \multirow{3}{*}{$140-112^{*}$} & 5 & $10.0 \mathrm{a}$ & $10.3 \mathrm{a}$ & $10.3 \mathrm{a}$ & $10.7 \mathrm{a}$ & $10.7 \mathrm{a}$ & $10.7 \mathrm{a}$ & $10.5 \mathrm{a}$ & $10.5 \mathrm{a}$ & $10.4 \mathrm{a}$ \\
\hline & 15 & $9.0 \mathrm{a}$ & $9.0 \mathrm{ab}$ & $9.0 \mathrm{ab}$ & $9.2 \mathrm{ab}$ & $9.3 \mathrm{ab}$ & $9.3 \mathrm{ab}$ & $9.3 a b$ & $9.3 \mathrm{ab}$ & $9.2 \mathrm{ab}$ \\
\hline & 25 & $7.8 \mathrm{a}$ & $8.2 \mathrm{ab}$ & $8.2 a b$ & $8.5 \mathrm{ab}$ & $8.5 \mathrm{ab}$ & $8.5 a b$ & $8.5 a b$ & $8.5 \mathrm{ab}$ & $8.4 \mathrm{ab}$ \\
\hline \multicolumn{2}{|l|}{ Standard error } & 0.23 & 0.23 & 0.23 & 0.23 & 0.22 & 0.23 & 0.22 & 0.22 & 0.22 \\
\hline
\end{tabular}

* The first concentration is the one used in the vegetative phase and the second in the productive phase.

Means followed with different letters indicate significant differences by Tukey test $(P \leq 0.05)$. 
phases, respectively, are adequate for normal plant development and that the number of stems per plant is significantly lower in treatments with a higher concentration of total $\mathrm{N}$, possibly because of a higher percentage of $\mathrm{N}-\mathrm{NH}_{4}$.

\section{Growth rates and indexes}

Although the calculated rates and indexes LAI, LMR, SLA, RGR and NAR did not obtain significant statistical differences in any of the three samples in each of the evaluated treatments, the trends of these variables to elucidate the physiological behavior of the submitted plants are presented to the treatments (Fig. 1).

As expected, the LAI presented a pattern of gradual growth in all treatments, with a tendency for better yield in the treatments with a lower amount of total $\mathrm{N}$, independent of the $\mathrm{NH}_{4}^{+}$concentration. When the foliar area intercepts the maximum photosynthetically active radiation, the optimal LAI is

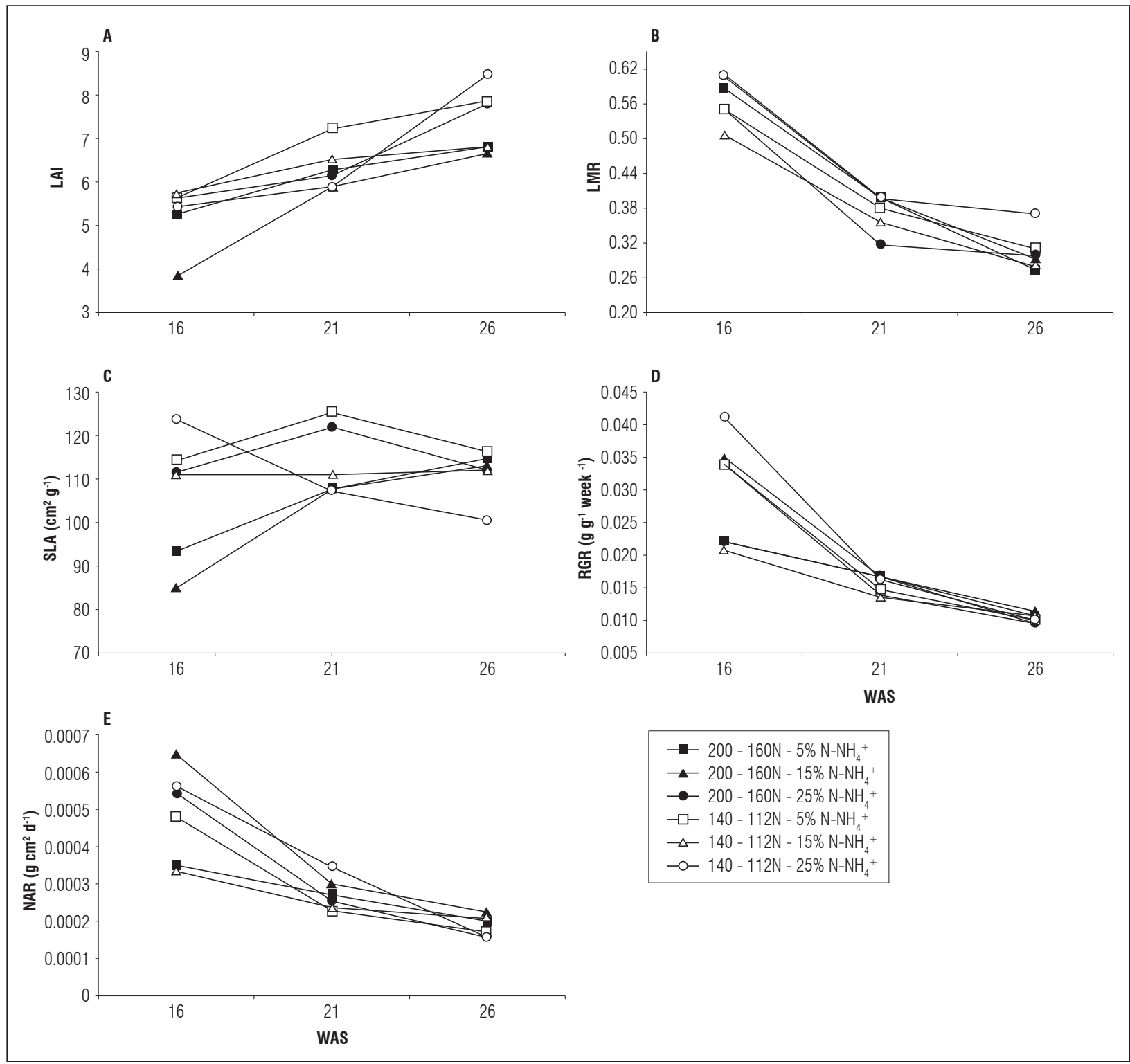

Figure 1. Behavior of standard carnation cv. Don Pedro planted in substrate and subjected to increases in the ammoniacal component of two fertigation formulas. (A) Leaf Area Index - LAI, (B) Leaf Mass Ratio - LMR, (C) Specific Leaf Area - SLA, (D) Relative Growth Rate - RGR, and (E) Net Assimilation Rate - NAR. WAS = weeks after sowing. 
obtained (Hunt, 1978); Criollo and García (2009), for radish, and Carranza et al. (2009), for lettuce, obtained maximum LAI values of 3.4 and 6.8, respectively. When Cárdenas et al. (2006) took into account the leaf area of entire carnation plants cv. Nelson grown on substrate, they reported maximum LAI values between 4.4 and 4.8; meanwhile, for the same $\mathrm{cv}$. at the second harvest peak, Baracaldo et al. (2010) reported maximum values between 7.5 and 8.7 , similar to those obtained in the present study. Therefore, LAI values depend, among other factors, on the type of plant, variety, phenological stage of development and agronomic management. When plants use $\mathrm{N}$ better, the metabolism of carbon is optimized because these processes modulate each other (Maldonado et al., 2013), and leaf area affects the photosynthetic carbon gain, which is reflected in the growth rate of the plant (Taiz and Zeiger, 2002) through synthesis of new biomass.

In all treatments, there was a decrease in the LMR from the beginning of the trial, which indicated an inversion of photoassimilates in the formation of other plant structures. The highest value of this variable was seen in the treatments $200-160-15 \% \mathrm{~N}^{-N_{4}}{ }_{4}{ }^{+}$ (commercial formula) and $140-112 \mathrm{~N}-25 \% \mathrm{~N}-\mathrm{NH}_{4}{ }^{+}$at 16 WAS; although the latter treatment had a higher proportion of ammonium, the accumulation of dry leaf mass was not affected.

In the formulas with more nitrogen, a tendency for greater translocation of dry mass was observed, in comparison with the treatments using the most conservative formulas. When increased to $25 \%$ of $\mathrm{N}-\mathrm{NH}_{4}{ }^{+}$in the formula with high $\mathrm{N}$, there was a decrease in the amount of biomass that is redirected to other structures of the plant. Therefore, it was inferred that, in the $200-160 \mathrm{~N}-5 \% \mathrm{~N}_{-} \mathrm{NH}_{4}{ }^{+}$treatment, the plants would direct more dry mass for the formation of flower buds, as observed at 26 WAS (Tab. 3). The marked decrease in the LMR from 16 to 21 WAS in all treatments coincided with the maximum AGR for the formation of flower buds (18 and 19 WAS). This relationship slowed down between 21 and 26 WAS when these structures reached their definitive development.

Table 3. Dry mass of carnation plants cv. Don Pedro grown on substrate, with decrease of the total $\mathbf{N}$ and increases in the component of $\mathrm{N}-\mathrm{NH}_{4}{ }^{+}$in the formula of fertigation.

\begin{tabular}{|c|c|c|c|c|c|c|c|}
\hline \multirow{2}{*}{$\begin{array}{c}\text { Week after } \\
\text { sowing }\end{array}$} & \multicolumn{2}{|c|}{ Treatment } & \multicolumn{5}{|c|}{ Dry mass (g) } \\
\hline & Total N (mg L-1) & $\mathrm{N}-\mathrm{NH}_{4}{ }^{+}(\%)$ & Leaves & Stems & Root & Flower bud & Total \\
\hline \multirow{6}{*}{16} & \multirow{3}{*}{$200-160^{*}$} & 5 & 16.9 & 11.1 & 1.0 & & 29.0 \\
\hline & & 15 & 13.5 & 7.9 & 0.7 & & 22.1 \\
\hline & & 25 & 15.0 & 12.4 & 0.8 & & 28.2 \\
\hline & \multirow{3}{*}{$140-112^{*}$} & 5 & 15.4 & 11.7 & 0.9 & & 28.0 \\
\hline & & 15 & 15.5 & 14.2 & 0.9 & & 30.6 \\
\hline & & 25 & 12.9 & 7.7 & 0.6 & & 21.2 \\
\hline \multirow{6}{*}{21} & \multirow{3}{*}{$200-160^{*}$} & 5 & 17.6 & 25.8 & 1.7 & 3.3 & 48.4 \\
\hline & & 15 & 16.4 & 23.1 & 0.9 & 0.9 & 41.4 \\
\hline & & 25 & 15.1 & 27.7 & 1.3 & 2.3 & 46.5 \\
\hline & \multirow{3}{*}{$140-112^{*}$} & 5 & 17.2 & 25.6 & 1.6 & 1.1 & 45.4 \\
\hline & & 15 & 18.0 & 28.3 & 1.4 & 1.8 & 49.4 \\
\hline & & 25 & 16.4 & 22.3 & 1.8 & 1.3 & 41.8 \\
\hline \multirow{6}{*}{26} & \multirow{3}{*}{$200-160^{*}$} & 5 & 17.7 & 33.1 & 2.9 & 12.3 & 65.9 \\
\hline & & 15 & 17.7 & 32.1 & 2.3 & 8.2 & 60.3 \\
\hline & & 25 & 20.9 & 35.2 & 2.6 & 7.6 & 66.3 \\
\hline & \multirow{3}{*}{$140-112^{*}$} & 5 & 20.2 & 35.0 & 2.4 & 10.8 & 68.4 \\
\hline & & 15 & 18.3 & 36.9 & 2.1 & 8.0 & 65.4 \\
\hline & & 25 & 25.8 & 33.5 & 2.1 & 11.2 & 72.6 \\
\hline
\end{tabular}

* The first concentration is the one used in the vegetative phase and the second in the productive phase. 
Although in treatments $200-160 \mathrm{~N}-5 \% \mathrm{~N}^{-} \mathrm{NH}_{4}{ }^{+}$and $200-160 \mathrm{~N}-15 \% \mathrm{~N}^{-} \mathrm{NH}_{4}{ }^{+}$, the SLA started low at 16 WAS (Fig. 1C); treatments $200-160 \mathrm{~N}-25 \% \mathrm{~N}^{-N_{4}}{ }^{+}$ and $140-112 \mathrm{~N}-5 \% \mathrm{~N}^{-\mathrm{NH}_{4}}{ }^{+}$had the same response profile, that is, they had a greater leaf area in relation to their dry mass, becoming sources of carbohydrates for sink organs between 16 and 21 WAS. The other treatments, although they were sources of assimilates, exported them less efficiently: in the $140-112 \mathrm{~N}$ $15 \% \mathrm{~N}^{-\mathrm{NH}_{4}}{ }^{+}$treatment, what was synthesized was exported without affecting the SLA, and, in the 140$112 \mathrm{~N}-25 \% \mathrm{~N}^{-} \mathrm{NH}_{4}{ }^{+}$, less than what was synthesized was translocated, reducing the SLA and maintaining a good amount of the biomass it synthesized in the leaves (Tab. 3). A high SLA indicates greater foliar area with light leaves and, consequently, greater capacity to capture light and produce carbohydrates. An SLA increase response indicates a constant partitioning of carbohydrates to sinks with high demand. With the most conservative fertigation formulas for total $\mathrm{N}$, the ammoniacal component played a preponderant role, where the highest percentage negatively affected the SLA, as seen in the $140-112 \mathrm{~N}-25 \% \mathrm{~N}^{-N_{4}}{ }^{+}$ treatment (Fig. 1C).

For RGR, two response groups were observed (Fig. 1D): in the group of treatments with a higher RGR, $140-112 \mathrm{~N}-25 \% \mathrm{~N}^{-} \mathrm{NH}_{4}{ }^{+}$stood out, which means that it was the most efficient treatment in the accumulation of new biomass to the system. This was reflected in leaves with the lowest SLA towards 26 WAS (Fig. 1C). This was explained by a reduction in the leaf area and an increase in the biomass, as shown in Tab. 3 , verifying that, in this treatment, the plants invested more dry mass in the leaves and flower buds at the expense of the stems and roots. In the second group,

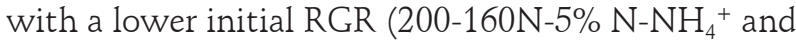
$140-112 \mathrm{~N}-15 \% \mathrm{~N}-\mathrm{NH}_{4}{ }^{+}$), regardless of the total $\mathrm{N}$ concentration, were not found the highest percentages of ammonium, which would stimulate the accumulation of new initial biomass. According to Grime and Hunt (1975), the highest RGR value was obtained in plants grown under conditions of greater fertility. In gerbera, an increase in the proportion of $\mathrm{NH}_{4}{ }^{+}$in the nutrient solution resulted in larger fresh and dried masses in the shoots and roots, with higher values in the 80:20 $\left(\mathrm{NO}_{3}{ }^{-}: \mathrm{NH}_{4}{ }^{+}\right)$ratio (Khalaj et al., 2017).

For Baracaldo et al. (2018), a reduction of total nitrogen and an increase in the $\mathrm{NH}_{4}^{+}: \mathrm{NO}_{3}{ }^{-}$ratio in the fertigation formula modified nutrient contents in carnation cv. Don Pedro plant tissue: with the lower content of total $\mathrm{N}$, the contents of $\mathrm{Cu}$ and $\mathrm{Zn}$ were significantly increased; the increase in $\mathrm{NH}_{4}{ }^{+}$significantly raised the contents of $\mathrm{N}$ and $\mathrm{Zn}$ and reduced $\mathrm{Mg}$. The highest $\mathrm{Mg}$ content was observed at 16 and 21 WAS in treatments with the lowest percentage of $\mathrm{NH}_{4}{ }^{+}(5 \%)$. Thus, from the nutritional point of view, the better yield in the conservative treatments for total nitrogen was understandable, with a lower percentage of ammonium.

Similar to RGR, the same response groups, possibly associated with the percentage of ammonium (Fig. 1E), were evident for NAR. For this parameter, the highest initial NAR value was observed in treatment $200-160 \mathrm{~N}-15 \% \mathrm{~N}-\mathrm{NH}_{4}{ }^{+}$. NAR represents the photosynthetic efficiency and decreases in the course of the development of the flowering stem, behavior that is associated with the leaf area existing in the first days after the pinch, when the leaves are more exposed to radiation and are more efficient at the assimilation of $\mathrm{CO}_{2}$. At the end of the cycle, similar values were seen in all treatments, with the smallest increases in total dry mass resulting from, among other factors, processes of foliar senescence, high planting density and plant architecture, which generate leaf shady, which causes a reduction in photosynthetic efficiency (Fig. 1E).

\section{Productivity and quality}

Taking into account the nitrogen factor, no statistically significant difference was found between the $200-160 \mathrm{~N}$ and $140-112 \mathrm{~N}$ treatments, with productivity averages of 83.5 and 87.9 stems $/ \mathrm{m}^{2}$ of greenhouse area, respectively; it follows that the same level of productivity could be achieved with less total nitrogen in the formula. However, the increases in $\mathrm{N}$ doses used by Thakulla et al. (2018) in exotic carnation var. Chabaud had a positive effect on most of the parameters attributed to growth and flowering, with the exception of the maximum dose, which delayed the time to flowering. For this variable, the minimum time was obtained with $300 \mathrm{~kg} \mathrm{ha}^{-1}$ of $\mathrm{N}$, while the maximum plant height, the length of the flowering stem and the number of branches were obtained with a rate of $400 \mathrm{~kg} \mathrm{ha}^{-1}$ of $\mathrm{N}$.

On the other hand, there was a decrease in the percentage of stalks in the Select quality grade as the percentage of ammonium increased, with a consequent increase in the percentage of flowering stems in the Fancy quality grade (Fig. 2). 


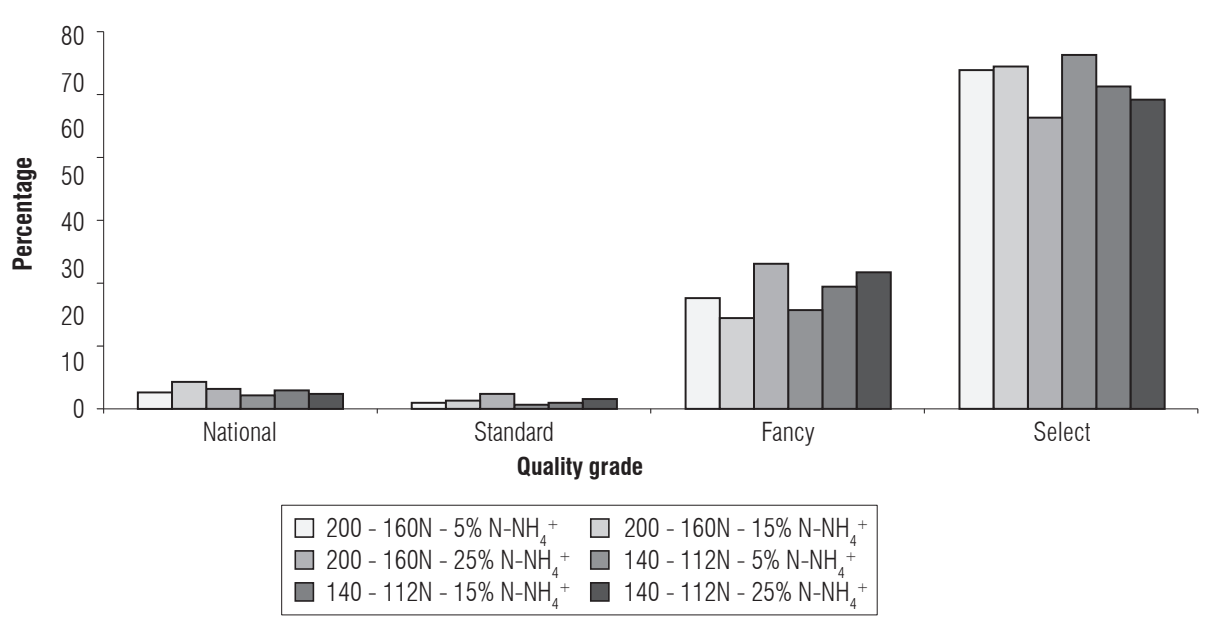

Figure 2. Quality of standard carnation flowering stems cv. Don Pedro planted in substrate subjected to different nitrogen fertilization treatments.

Although there would not be a statistical difference, productivity would increase to four more stems per $\mathrm{m}^{2}$ with a higher degree of quality and the economy in the cost of the fertilizer and in the environmental impact would result in higher profits for producers.

Achievements in productivity and quality based on particular $\mathrm{NH}_{4}{ }^{+}: \mathrm{NO}_{3}-$ ratios were addressed by $\mathrm{Ta}$ batabaei et al. (2006) in strawberries, based on better calcium-based nutrition and increases in leaf area and photosynthesis rate, and better SPAD values and quantum yield of PSII (Fv/Fm) (Roosta, 2014), or, in tulips, with maximum concentrations of $\mathrm{Ca}$ and $\mathrm{Mg}$, flower longevity, dry mass and optimal N, P, K (Abasi et al., 2016).

\section{Nitrogen use efficiency - NUE}

At 21 WAS, the plants of the $140-112 \mathrm{~N}$ treatment presented a significantly higher NUE value compared to the treatment with the highest $\mathrm{N}$ concentration, indicating that the gain of dry mass resulted from a more efficient use of $\mathrm{N}$ (Fig. 3). Dry mass production is closely related to NUE. In this experiment, no statistically significant differences were found in the dry mass values (Tab. 3), hence the plants fertilized with the lowest concentration of $\mathrm{N}$ had higher NUE values, in a manner consistent with that reported by Good et al. (2004) and Lupini et al. (2017).

With the onset of the reproductive phase, according to Kant (2018), there is a parallel breakdown of

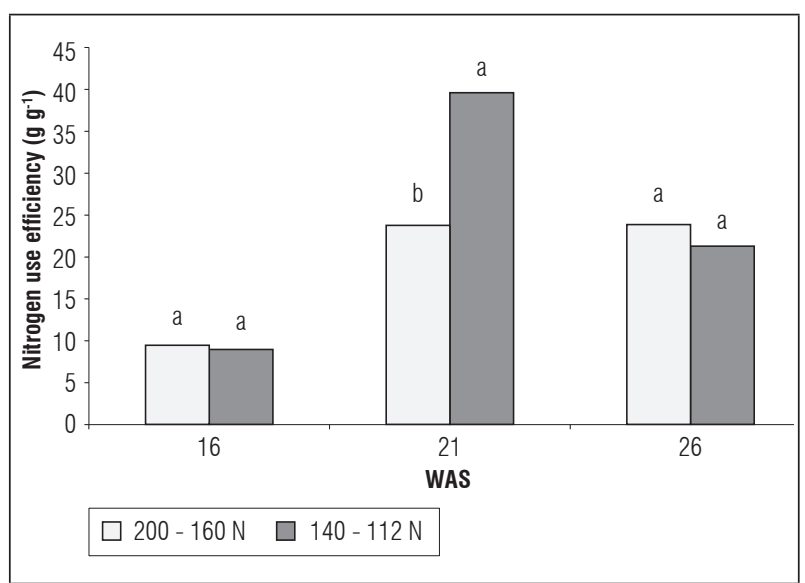

Figure 3. Efficiency in the use of nitrogen in standard carnation plants cv. Don Pedro planted in substrate under different nitrogen fertilization treatments. Means followed with different letters indicate significant differences by Tukey test $(P \leq 0.05)$.

proteins in the process of foliar senescence, and the released amino acids and other $\mathrm{N}$ compounds must be efficiently directed towards sink organs. This step is a critical component to improving NUE and thus avoiding wasted proteins and amino acids.

In oats with applications of 80,100 and $120 \mathrm{~kg} \mathrm{ha}^{-1}$ of $\mathrm{N}$, it was found that NUE decreased significantly with increasing doses of $\mathrm{N}$, with values of 38.3, 34.7 and $30.2 \mathrm{~kg}$ of grain $/ \mathrm{kg}$ of $\mathrm{N}$ applied, respectively (Rahman et al., 2011). This coincides with that 
obtained in this study, where the higher concentrations of $\mathrm{N}$ (200 and $160 \mathrm{mg} \mathrm{L}^{-1}$ ) had a lower NUE than the lowest concentration. To achieve a greater NUE in carnation cv. Gaduina, a constant release of the $\mathrm{N}$ incorporated in the soil is required (Muthukrishnan et al., 2014).

\section{CONCLUSIONS}

In both fertigation formulas:

- similar productivity and qualities were obtained, and the formula with less total $\mathrm{N}$ had better NUE, mitigating the negative environmental impact of this nutrient.

- the ammoniacal component plays a preponderant role: the number of flowering stems per plant decreased as the ammonium component increased, similar to that observed with the percentage of flowering stems in the Select quality grade.

\section{ACKNOWLEDGMENTS}

The authors thank the Asociación Colombiana de Exportadores de Flores - Asocolflores, the Centro de Innovación de la Floricultura Colombiana - Ceniflores, the government of Cundinamarca and the Universidad Nacional de Colombia, co-financing entities and managers of the project "Fortalecimiento de la competitividad del sector floricultor colombiano mediante el uso de ciencia, tecnología e innovación aplicadas en Cundinamarca", in which the present study was developed. The authors also thank Brenntag Colombia S.A. for supplying the nutritional solutions.

Conflict of interests: the manuscript was prepared and reviewed with the participation of the authors, who declare that there exists no conflict of interest that puts in risk the validity of the presented results.

\section{BIBLIOGRAPHIC REFERENCES}

Abasi, H., M. Babalar, H. Lessani, and R. Naderi. 2016. Effects of nitrogen form of nutrient solution on uptake and concentration macro element and morphological trait in hydroponic tulip. J. Plant Nutr. 39(12), 1745-1751. Doi: 10.1080/01904167.2016.1201110

Acuña C., J.F. and D.M. Ortiz P. 2004. Estructuras de invernadero: la experiencia colombiana. pp. 83-107. En: Acuña C., J.F., D.L. Valera M., and J.C. Avendaño (eds.)
Invernaderos: La experiencia iberoamericana. Programa Cyted, Almería, Spain.

Baracaldo, A.P., M.C. Díaz, V.J. Flórez, and C.A. González. 2018. Efecto de la disminución de $\mathrm{N}$ total y aumento de $\mathrm{NH}_{4}{ }^{+}$en la fórmula de fertirriego en el cultivo de clavel. Rev. Colomb. Cienc. Hortic. 12(3), 658-667. Doi: 10.17584/rcch.2018v12i3.8062

Baracaldo A., A.P., A. Ibagué O., and V.J. Flórez R. 2010. Tasas e índices de crecimiento a segundo pico de cosecha en clavel estándar cv. Nelson cultivado en suelo y en sustratos. Agron. Colomb. 28(2), 209-217.

Barker, A. and G. Bryson. 2007. Nitrogen. pp. 22-23. In: Barker, A.V. and D.J. Pilbeam (eds.). Handbook of plant nutrition. CRC Press. Taylor and Francis, Boca Raton, FL.

Bar-Yosef, B. 2008. Fertigation management and crops response to solution recycling in semi-closed greenhouses. pp. 341-424. In: Raviv, M. and J.H. Lieth (eds.). Soilless culture: theory and practice. Elsevier, Amsterdam. Doi: 10.1016/B978-044452975-6.50011-3

Cabrera, R.I. 2006. Consideraciones sobre nutrición mineral y fertilización en rosas. pp. 145-161. In: Flórez R., V.J., A. de la C. Fernández, D. Miranda, B. Chaves C., and J.M. Guzmán P. (eds.). Avances sobre fertirriego en la floricultura colombiana. Unibiblos, Bogota.

Cameron, K.C., H.J. Di, and J.L. Moir. 2013. Nitrogen losses from the soil/plant system: a review. Ann. Appl. Biol. 162(2), 145-173. Doi: 10.1111/aab.12014

Cárdenas M., C.A., I.F. Rivera G., V.J. Flórez R., B. Chaves C., and W. Piedrahíta C. 2006. Growth analysis of standard carnation cv. 'Nelson' in different substrates. Acta Hortic. 718, 623-629. Doi: 10.17660/ ActaHortic.2006.718.73

Carranza, C., O. Lanchero, D. Miranda, and B. Chaves. 2009. Análisis del crecimiento de lechuga (Lactuca sativa L.) 'Batavia' cultivada en un suelo salino de la Sabana de Bogotá. Agron. Colomb. 27(1), 41-48.

Carrillo P., I.F., B. Mejía M., and A. Franco H.F. 1994. Manual de laboratorio para análisis foliares. Cenicafé, Chinchina, Colombia.

Criollo, H. and J. García. 2009. Efecto de la densidad de siembra sobre el crecimiento de plantas de rábano (Raphanus sativus L.) bajo invernadero. Rev. Colomb. Cienc. Hortic. 3(2), 210-222. Doi: 10.17584/ rcch.2009v3i2.1214

Daza, M.C., J. Díaz, E. Aguirre, and N. Urrutia. 2015. Efecto de abonos de liberación lenta en la lixiviación de nitratos y nutrición nitrogenada en estevia. Rev. Colomb. Cienc. Hortic. 9(1), 112-123. Doi: 10.17584/ rcch.2015v9i1.3750

Dufour, L. and V. Guérin. 2005. Nutrient solution effects on the development and yield of Anthurium andreanum Lind. in tropical soilless conditions. Sci. Hortic. 105(2), 269-282. Doi: 10.1016/j.scienta.2005.01.022 
Escandón L., J.D. 2009. Propuesta logística para el desarrollo de la exportación de rosas y claveles a estados unidos para la comercializadora Export Flexy Ltda. Undergraduate, Pontificia Universidad Javeriana, Bogota.

FAO. 2017. World fertilizer trends and outlook to 2020. Summary report. Food and Agriculture Organization of United Nations, Rome.

Flórez R., V.J., R. Parra R., M. Rodríguez S., and D.E. Nieto C. 2006a. Características y fundamentos del proyecto "Producción más limpia de rosa y clavel con dos técnicas de cultivo sin suelo en la Sabana de Bogotá". pp. 3-40. In: Flórez R., V.J., A. de la C. Fernández M., D. Miranda L., B. Chaves C., and J.M. Guzmán P. (eds.). Avances sobre fertirriego en la floricultura colombiana. Unibiblos, Bogota.

Flórez R., V.J., D. Miranda L., B. Chaves C., L.A. Chaparro T., C.A. Cárdenas M., and A. Farías A. 2006b. Parámetros considerados en el análisis de crecimiento en rosa y clavel en los sistemas de cultivo en suelo y en sustrato. pp. 43-52. In: Flórez R., V.J., A. de la C. Fernández, D. Miranda L., B. Chaves C., and J.M. Guzmán P. (eds.). Avances sobre fertirriego en la floricultura colombiana. Unibiblos, Bogota.

Florian-Martínez, P. and D. Roca. 2011. Sustratos para el cultivo sin suelo. Materiales, propiedades y manejo. pp. 37-78. In: Flórez R., V.J. (ed.). Sustratos, manejo del clima, automatización y control en sistemas de cultivo sin suelo. Editorial Universidad Nacional de Colombia, Bogota.

Gárate, A. and I. Bonilla. 2013. Nutrición mineral y producción vegetal. pp. 143-164. In: Azcón-Bieto, J. and M. Talón. (ed.). Fundamentos de fisiología vegetal. $2^{\text {nd }}$ ed. McGraw Hill - Interamericana de España, Madrid.

Good, A.G., A.K. Shrawat, and D.G. Muench. 2004. Can less yield more? Is reducing nutrient input into the environment compatible with maintaining crop production? Trends Plant Sci. 9(12), 597-605. Doi: 10.1016/j.tplants.2004.10.008

Grime, J.P. and R. Hunt. 1975. Relative growth-rate: its range and adaptive significance in a local flora. J. Ecol. 63(2), 393. Doi: $10.2307 / 2258728$

Hawkesford, M., W. Horst, T. Kichey, H. Lambers, J. Schjoerring, I. Møller, and P. White. 2012. Functions of macronutrients. pp 135-189. In: Marschner, H. and P. Marschner (eds.). Mineral nutrition of higher plants. $3^{\text {rd }}$ ed. Academic Press, San Diego, CA. Doi: 10.1016/ B978-0-12-384905-2.00006-6

Hunt, R. 1978. Plant growth analysis. Edward Arnold Publishers, London.

ICA, Instituto Colombiano Agropecuario; MADR, Ministerio de Agricultura y Desarrollo Rural. 2015. Relación entre el consumo aparente de fertilizantes y la superficie bajo uso agrícola. In: Dane: www.dane.gov.co; consulted: April, 2017.
Jin, X., G. Yang, C. Tan, and C. Zhao. 2015. Effects of nitrogen stress on the photosynthetic $\mathrm{CO}_{2}$ assimilation, chlorophyll fluorescence, and sugar-nitrogen ratio in corn. Sci. Rep. 5, 1-9. Doi: 10.1038/srep09311

Li, J., J.M. Zhou, and Z.Q. Duan. 2007. Effects of elevated $\mathrm{CO}_{2}$ concentration on growth and water usage of tomato seedlings under different ammonium/nitrate ratios. J. Environ. Sci. 19(9), 1100-1107. Doi: 10.1016/ S1001-0742(07)60179-X

Kant, S. 2018. Understanding nitrate uptake, signaling and remobilisation for improving plant nitrogen use efficiency. Semin. Cell Dev. Biol. 74, 89-96. Doi: 10.1016/j. semcdb.2017.08.034

Khalaj, M.A., S. Kiani, A.H. Khoshgoftarmanesh, and R. Amoaghaie. 2017. Growth, quality, and physiological characteristics of gerbera (Gerbera jamesonii L.) cut flowers in response to different $\mathrm{NO}_{3}{ }^{-}: \mathrm{NH}_{4}{ }^{+}$ratios. Hortic. Environ. Biotechnol. 58(4), 313-323. Doi: 10.1007/s13580-017-0067-7

Kiba, T., T. Kudo, M. Kojima, and H. Sakakibara. 2011. Hormonal control of nitrogen acquisition: Roles of auxin, abscisic acid, and cytokinin. J. Exp. Bot. 62(4), 13991409. Doi: $10.1093 / j x b / e r q 410$

Kumar, A., G.-S. Rana, R. Sharma Prince, and D.-S. Dahiya. 2016. Flowering of carnation as influenced by different levels of nitrogen and Azotobacter strains. Indian Hortic. J. 6(2), 222-225.

Lupini, A., M.P. Princi, F. Araniti, A.J. Miller, F. Sunseri, and M.R. Abenavoli. 2017. Physiological and molecular responses in tomato under different forms of $\mathrm{N}$ nutrition. J. Plant Physiol. 216, 17-25. Doi: 10.1016/j. jplph.2017.05.013

Maldonado, J.M., E. Agüera, and R. Pérez-Vicente. 2013. Asimilación del nitrógeno y del azufre. pp. 287-303. In: Azcón-Bieto, J. and M. Talón (ed.). Fundamentos de fisiología vegetal. $2^{\text {nd }}$ ed. McGraw Hill - Interamericana de España, Madrid.

Muthukrishnan, R., K. Arulmozhiselvan, M. Jawaharlal, and T. Padmavathi. 2014. Recovery of fertilizer nitrogen by carnation grown with nutripellet pack and soil nitrogen retention using $15 \mathrm{~N}$ tracer. Res. Envirom, Life Sci. 7(4), 271-274.

Ordoñez D., N. and A. Bolivar G. 2014. Levantamiento agrológico del Centro Agropecuario Marengo (CAM). Instituto Geográfico Agustín Codazzi - IGAC, Bogota.

Rahman, M.A., M.A.Z. Sarker, M.F. Amin, A.H.S. Jahan, and M.M. Akhter. 2011. Yield response and nitrogen use efficiency of wheat under different doses and split application of nitrogen fertilizer. Bangladesh J. Agric. Res. 36, 231-240. Doi: 10.3329/bjar.v36i2.9249

Reid, M. and D. Hunter. 2000. Manejo de la poscosecha. Biología y tecnología de la poscosecha. pp. 165-181. In: Pizano de Marquez, M. (ed.). Clavel (Dianthus caryophyllus). Ediciones Hortitecnia, Bogota. 
Roosta, H.R. 2014. Effect of ammonium:nitrate ratios in the response of strawberry to alkalinity in hydroponics. J. Plant Nutr. 37(10), 1676-1689. Doi: 10.1080/01904167.2014.888749

Schipper, L.A., W.D. Robertson, A.J. Gold, D.B. Jaynes, and S.C. Cameron. 2010. Denitrifying bioreactors: an approach for reducing nitrate loads to receiving waters. Ecol. Eng. 36(11), 1532-1543. Doi: 10.1016/j. ecoleng.2010.04.008

Tabatabaei, S.J., L.S. Fatemi, and E. Fallahi. 2006. Effect of ammonium: nitrate ratio on yield, calcium concentration, and photosynthesis rate in strawberry. J. Plant Nutr. 29(7), 1273-1285. Doi: 10.1080/01904160600767575

Taiz, L. and E. Zeiger 2002. Plant physiology. Sinauer Associates Publishers, Sunderland, MA.

Thakulla, D., A. Khanal, and L.R. Bhatta. 2018. Adaptability of exotic variety of carnation (Dianthus
Caryophyllus var. Chabaud) under different doses of nitrogen. Int. J. Hort. Agric. 3(2), 1-3. Doi: 10.15226/2572-3154/3/2/00120

Ucar, Y., S. Kazaz, F. Eraslan, and H. Baydar. 2017. Effects of different irrigation water and nitrogen levels on the water use, rose flower yield and oil yield of Rosa damascena. Agric. Water Manag. 182, 94-102. Doi: 10.1016/j.agwat.2016.12.004

Vojtíšková, L., E. Munzarová, O. Votrubová, A. Rihová, and B. Juricová. 2004. Growth and biomass allocation of sweet flag (Acorus calamus L.) under different nutrient conditions. Hydrobiol. 518, 9-22. Doi: 10.1023/B:HYDR.0000025052.81373.f3

Zhang, H., D. Chi, Q. Wang, J. Fang, and X. Fang. 2011. Yield and quality response of cucumber to irrigation and nitrogen fertilization under subsurface drip irrigation in solar greenhouse. Agric. Sci. China. 10(6), 921930. Doi: 10.1016/S1671-2927(11)60077-1 